\title{
Poltical Culture and Virtual Democracy In Indonesia: The Campaign of President's Election 2018-2019
}

\author{
Suwandi Sumartias ${ }^{1}$, Rosnandar Romli ${ }^{2}$, FX. Ari Agung Prastowo ${ }^{3}$, Dian Wardiana Sjuchro ${ }^{4}$ \\ $\left\{{ }^{1}\right.$ suwandi.sumartias@unpad.ac.id $\}$ \\ 1,2,3,4 Universitas Padjadjaran, Indonesia
}

\begin{abstract}
The euphoria of democracy in the direct elections of the 2019 RI president, two presidential candidates Joko Widodo and Prabowo Subianto, campaigned from 23 September 2018 to 13 April 2019. Social media, especially Twitter, became a very massive campaign media. Through the Virtual Ethnographic as research method, the research show: the existence of a new political culture of netizens; freedom of expression of netizens is very free, even goes beyond the limits of social ethics, common sense and very emotional; the polarization of support strengthened between the haters and lovers of the presidential candidate supporters. Recommendations, there are need for education and democratic literacy for netizens to be more responsible and ethical in speaking on social media.
\end{abstract}

Keywords: political, culture, virtual democracy

\section{Introduction}

The euphoria of virtual democracy has encouraged the formation of a new political culture among netizens, namely cyber culture. A new platform political culture, marked by high political activity, among others: the presidential election campaign on social media in 2019 , especially Twitter.

The globalization flow has created changes in developing countries, as like Indonesia, especially the era of virtual democracy. Online democracy in the presidential election in 2019 , the candidates campaigned for their exellence ideas and programs to attract netizens to vote for them. The netizens gave various responses both positive and negative. Since the presidential election in 2014, social media has become one of the campaign media by the presidential and vice-presidential candidates on Twitter. Likewise by campaigners, volunteers, buzzers and or political influencers. Twitter is a venue for campaigning and political interaction between netizens, politicians and candidates. Social media, twitter is a media for forming opinions and issues carried out by candidates and supporters. For example done by creating anonymous accounts to hold polls on twitter or play political issues.

Some anonymous accounts that often play political issues include @kakekdetektif and @ maspiyuuu. Both accounts are active on twitter. The @ kekekdetektif account often plays proJokowi issues, while @ maspiyuuu has a tendency to support the government's opposition camp. 
[1]. The use of social media for the benefit of political campaign channels cannot be separated from the name of Barack Obama as a candidate for the US presidential candidate in 2008 which for the first time intensively used Facebook and Twitter as a channel for campaigning (see Smith, 2012, Wooley et al, 2010). Obama's success in maximizing the ability of social media as a campaign channel can be said to be a kind of trigger for the rise of studies on social media. [2]. The era of social media today bring significants change into democracy in Indonesia. Social media bring the expansion of the public space in cyberspace, citizens can directly deliver aspirations regarding the state policy. However, on the other side, social media vulnerable to abuse because of many the anonymous account, which acts as the buzzer political influence public perceptions and to get political support but is not elegant way. This shows that social media provides a challenge to democracy, including Indonesia as a third largest country that has access to the social media in the world's. The results of the study showed that the impact of social media in Indonesia has brought problems such as hoax, which is currently a serious concern of the government. Attempts were made through the campaign against hoax and make regulation, Information and Electronic Transactions Law (ITE Law), which aims to regulate the use of social media and to prevent hoaxes. The life of democracy in Indonesia receive significant challenges,but of the repressive laws against users of social media may actually weaken the democratic life in Indonesia. [3]

Presidential candidates's contestation on social media and the support of each candidate's netizens fought a very high-tension " hashtag war". Political liberalization has placed politics, not only as an arena for selling ideas and services, also triggering new problems. How political competition the presidential candidates and their supporters are trapped in is an extraordinary polarization and dichotomy. Various symbols of religion, ethnicity, culture and also social identity (groups) with nuances of ethnicity, religion, race and groups in such a way strengthen and give birth to haters and lovers. And in turn will threaten the integrity of the Unitary Republic of Indonesia as a nation. Ironically, this phenomenon appears until now, although the presidential election was over on April 17, 2019.

The political domain is very diverse, especially in Indonesia, with 11 supporting political parties, social organizations, religious organizations and so on. With this multi-party party, various efforts that are not easy to build or market in political brands are needed. Instead of the diversity of ideology and mission of political parties, even many social and religious organizations have become "on-bottom" political parties. And in turn, how difficult it is to build a political brand, even potential voters are very difficult to make their choice. Negative effects that often arise, conflicts of interest and social appear between voters. And it is proven in social media that there is a conflict of interest with various utterances between the supporters of the two presidential candidates in the 2019 elections, very dynamic, even leading to a "war" of continuous speech. Appearing the "haters" and "lovers" groups.

Dialectics of online democracy becomes an interesting study to continue to be discussed as an alternative social media, including formulating legal policies that can shelter and protect it, so as to find an ideal platform that can be guarded and adhered to together towards a prosperous and harmonious society. Another challenge is the extent and how strengthening the substance of online democracy is in the common interest of all elements of government and its people, because the effectiveness of social media as an alternative democratic channel depends on the selection of issues raised online, particularly issues of concern and concerns of the public interest (eg corruption, change climate, and education for the poor). Ideas selected and raised online must have the support of community leaders and mass media as a form of social legitimacy. [4]

Negative impact in the development of social media that rife in Indonesia brought the issue 
of the outbreak of hoax. The phenomenon of anonymous accounts of hoax spreaders began to bloom since the 2000s. Where anonymous account on social media twitter named initially @ triomacan200 later days switch @ TM2000Back is often problematic with the law for spreading hoax information. This account was a concern netizen during the election of the governor of DKI Jakarta at 2012 Year 's ago. Where the political topics raised by the Trio Macan considered able to influence public opinion and political choice. However, due to the large number of hoaxes raised by this anonymous account causing the owner of the Trio Macan account many reported by the victim and eventually arrested by the police and imprisoned. This phenomenon indicates that the mingling of opinion in the democratic contestation in the reform era is accompanied by the widespread hoax that was deliberately for political weapons. [3]

On the other hand, we understand that political education and the competence of politicians are still far from the expectations and goals of democracy and or politics. The phenomenon of the personal closeness of candidates or politicians with certain citizens or groups, not infrequently also accompanied by 'transactions' of money politics, further worsening the absence of a positive political brand.

The practice of democracy in social media (virtual democracy), grew in the last 10 years. Dialectics of online democracy is the process of giving public or people's space to criticize and dialogue about the extent to which the country's elite is serious in managing the mandate of the people that have been given. And political phenomena lead netizens to cyber culture, as a new culture. The challenge, virtual democracy, is still not accompanied by a level of awareness that is based on rational, argumentative and critical thinking. Democracy is just a "party" that is very closely related to the rhetoric and appearance of celebration. Shows on social media have not been supported by the power of digital media literacy and adequate political education.

In this sense, political culture functions as the determinant of political behavior. The second point of view seems to be the most popular in political science, such as those considering the contribution of political culture in shaping democracy. It can be seen in the works of Almond and Verba, Pye, Putnam, Rosenbaun, Kavanagh, Eckstein, and Diamond.4 These authors believe that democracy requires particular values, beliefs and attitudes toward the objects of politics. It can apparently be seen in their cross-national studies of political culture which recognize that to some extent the different political cultures of each nation influences the nature of their democracies.[6]

The hashtag war or hashtag between supporters of the two candidates took place mainly on Twitter and Facebook long before the official schedule of the 2019 Presidential Election campaign period began, even before the Genera Election Commissions (KPU) officially set the Presidential and Vice Presidential Candidates in the 2019 Presidential Election. Competition competition in social media is very tight causing potential violations campaign rules in campaigning will be greater, especially in the form of hoaxes and hate speech which is an ethnic, religion, race and groups (SARA) ). [1]

Some research on social media then stretches from the study of changes in political constellation in a country caused by the presence of social media such as Tufecki and Wilson (2012) or Bakardjieva (2011), to research that specifically examines the use of Twitter in the context of campaigns such as those conducted by Vergeer and Hermans (2013) who examined how candidates for legislative candidates in the 2010 elections in the Netherlands used Twitter. These include Himelboim's (2013) study which examines how exposed from a political perspective in conversations on Twitter in the election of senate members in the United States. Specifically for Indonesia, Mulyana (2013: 23) revealed that there has not been much political communication research involving social media. Research on social media in Indonesia has at least begun to be heavily discussed and reviewed only in 2012 when the Jakarta Governor 
Election took place (see Mulyana 2013, Abugaza, 2013). Yet according to data from the UI Communication Studies Center (PusKaKom UI) and the Indonesian Internet Services Association and Organizers (APJII) shows that Indonesia is one of the countries with increasing internet and social media user penetration rates each year. [2].

Pye explains: The theory of political culture was developed in response to the need to bridge a growing gap in the behavioral approach in political science between the level of microanalysis based on psychological interpretations of the individual's political behavior and the level of macro-analysis based on the variables common to political sociology.[6]

\section{Research Method}

This study uses virtual ethnography, which seeks to interpret the phenomenon or reality of netizens' culture on social media, especially those relating to political culture and virtual democracy during the 2018-2019 Presidential Election campaign on Twitter. Tom Boellstorff, stated that virtual ethnographic research, basically has the same principles as ethnographic research, where the sequence to run and establish ethnography using virtual online areas for research sites. [7]

\section{Discussion}

The presidential election campaign in 2018-2019 is the activity of the RI presidential candidates to convey ideas and excellent programs as presidential candidates among citizens, especially on social media. And the election campaign activities are more interesting to study, because the practice of virtual democracy of netizens as a new political culture is cyber culture.

Since 2014, the RI presidential campaign has been carried out through various media, including social media. According to the research of Firmansjah, et al. (2017), the results show that during the 2014 presidential election it can be said that factually Twitter has become a political campaign channel that is used massively by both supporters of candidate candidates. Twitter presence factor which is used massively is what then makes the face of the 2014 presidential election campaign different from the campaign in the elections in previous years. The results showed that Prabowo is constructed by supporters of Twitter accounts as a highly intelligent, resolute and strong. While Jokowi was constructed by supporters as a populist figure, simple and honest. [2].

Likewise, in the 2019 presidential election campaign, two camps of presidential candidates competing for " \# war " on social media (twitter) were very high in intensity. Example: \# 2019gantipresiden gets 76,440 tweets. His exposure was not much different from \# Jokowi2Periode, which reached 157,718 impressions. This data was also taken as of July 25, 2018, until 19.30 WIB. Interestingly, the exposure characteristics of \# 2019 non-residents tend to be different from the \# Jokowi2 Periode. As many as 42 percent come from accounts with less than one thousand followers. Meanwhile, the followers category is less than 100 reaching 38 percent. The top contributor for \# 2019gantipresiden according to Tweetreach is the @ roninpribumi account. This account is able to give 78.1 thousand impressions on Twitter conversations for \# 2019 President. In line with the top contributor \# Jokowi2Periode, the @ roninpribumi account seems to be a buzzer type account. (https://tirto.id/dkxA) 

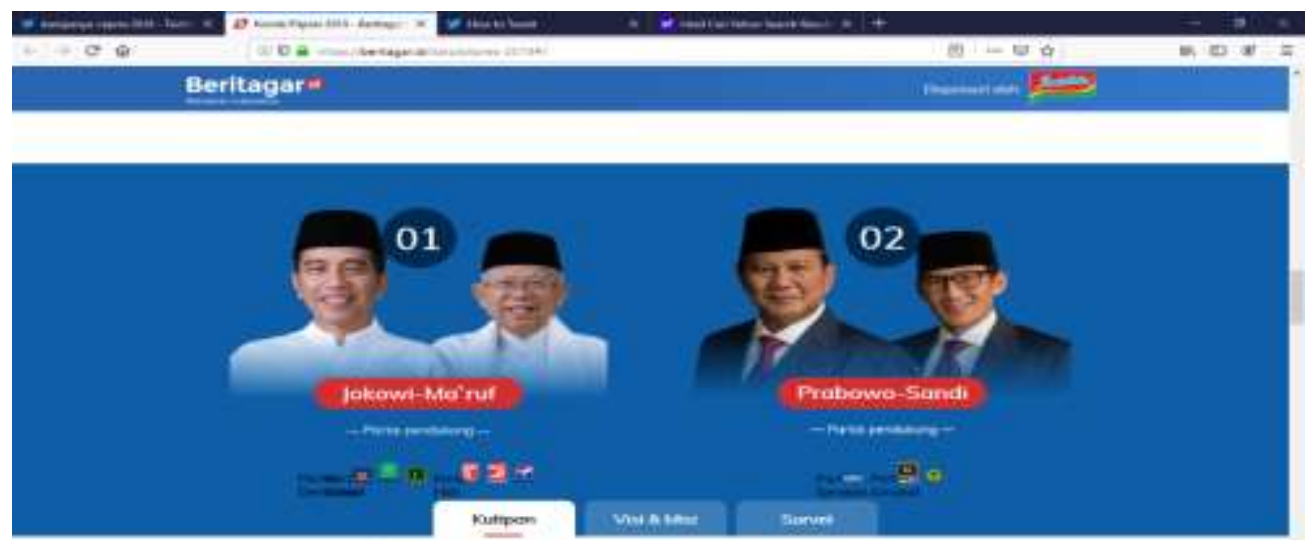

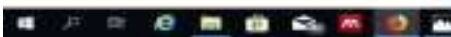

Figure 1: President Candidate of Republic Indonesia 2019

From the picture above, through the "beritagar" account shows that there are two RI presidential candidates namely Jokowi-Ma'ruf with serial number 01 and Prabowo-Sandi with serial number 02. Pair 01 is supported by the PDI-P party; National Democrats, PKB, PPP, Golkar and PSI and Hanura. Pair 02 is supported by PAN, Gerindra, PKS and Democrat parties. Both candidates conducted campaigns on social media with their personal accounts and the influencers' and / or political buzzer's accounts. And the hashtag war on Twitter is very dynamic and hot.

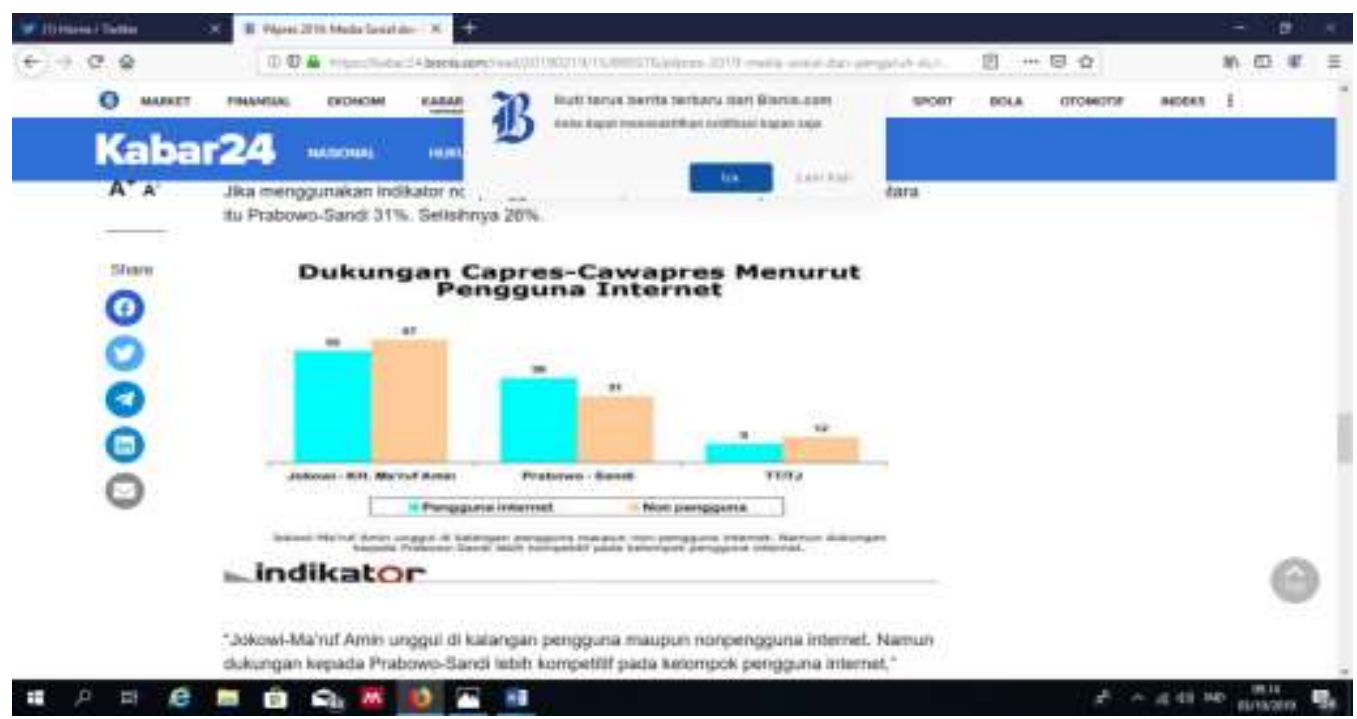

Figure 2 above, through the Kabar24 account, shows internet user support for both presidential and vice presidential candidates, the Jokowi-Ma'ruf pair is superior (52\%) and Prabowo-Sandi $(39 \%)$. 


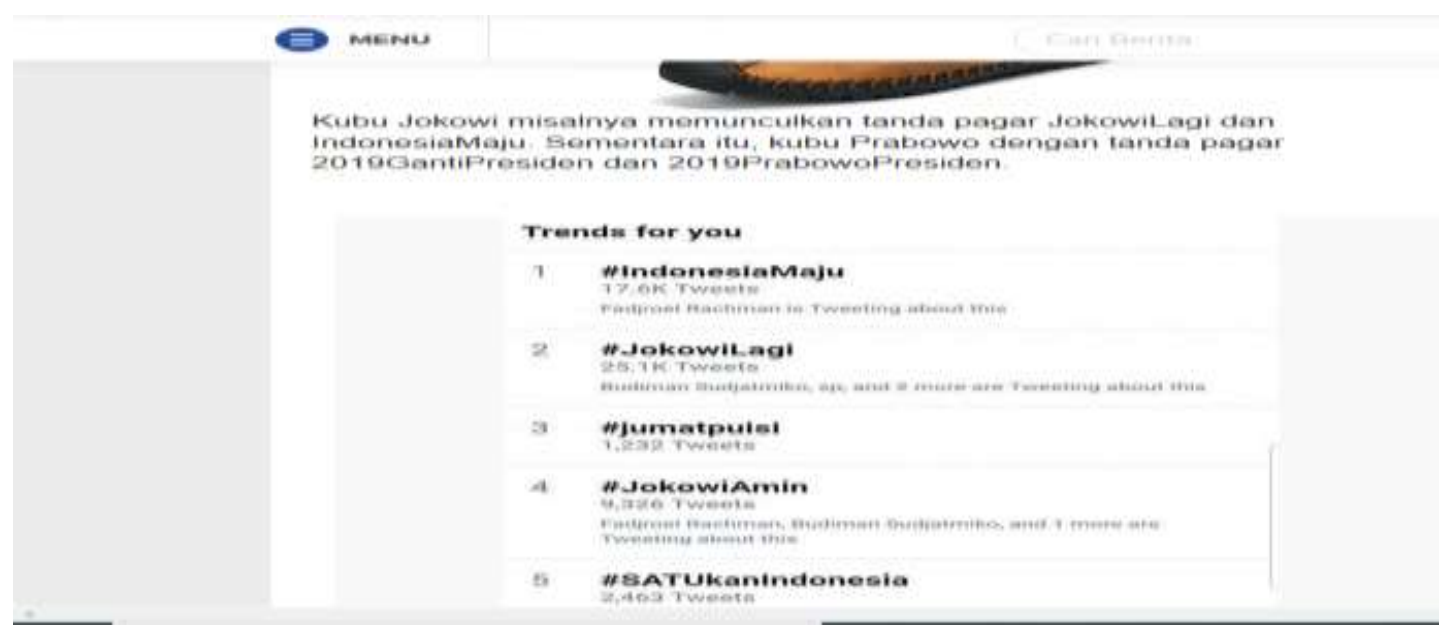

( Photo: Ismail Fahmi)

Figure 3, shows Ismail describing a number of popular hashtags on Twitter after drawing the serial number. The fence mark in Jokowi's camp, the top two rank is the Jokowi fence sign again with 5,033 cuitans and Indonesia Maju with 3,225 cuitans.

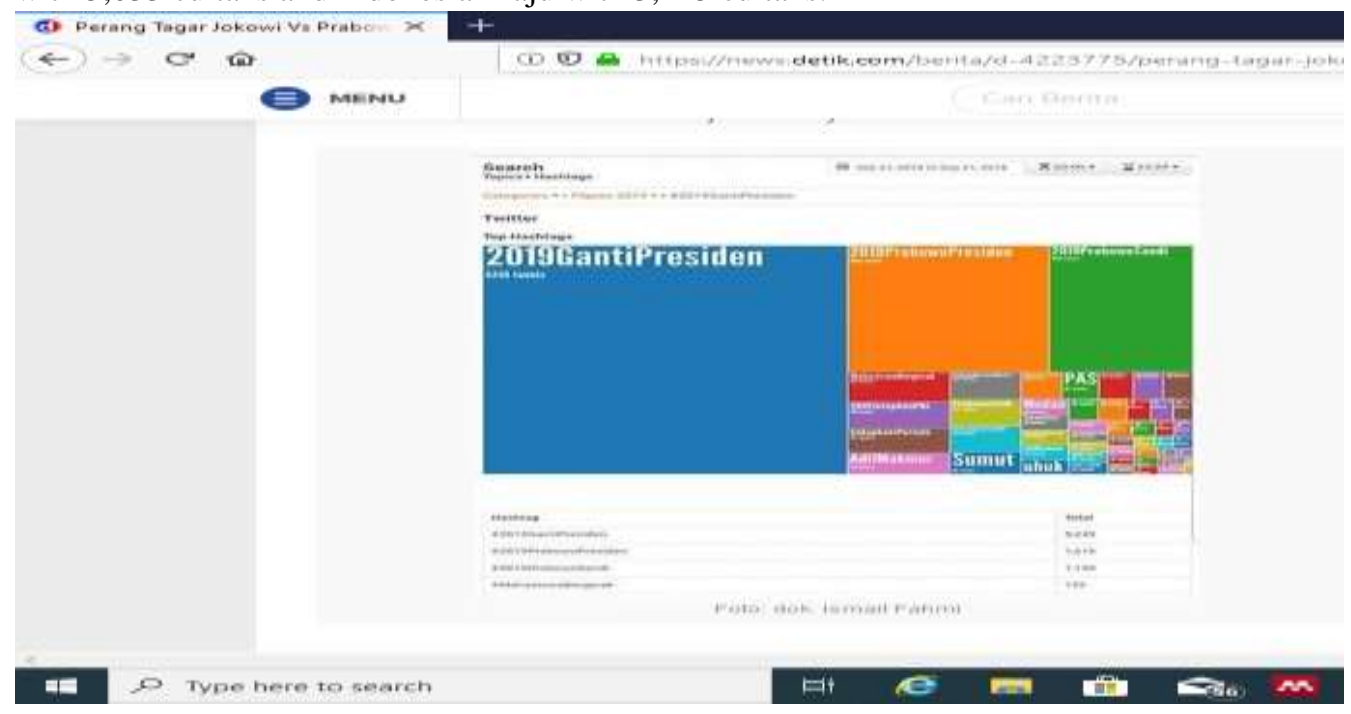

Figure 4, shows, Prabowo's stronghold, popular fence signs are \#2019gantipresiden with 6,068 tweets and 2019 Prabowo Presidents as many as 1,845 cuitans.

The virtual democracy of the presidential candidates' campaign through Twitter, seems to have a unique and attractive appeal for candidiates and netizens. Twitter as a platform for political reporting is easier to use as a campaign media for candidates and netizens, buzzers or volunteers from both candidates to interact with each other. The hashtag war (\#) of netizens, provides narration and symbols as representations of both candidates and is easy to remember. 
Report titled Essential Insights Into the Internet, Social Media, Mobile, and e-Commerce Use Around the World (2017), a media research company based in the United Kingdom, social media users in Indonesia currently reaches 132 million people. Of that number, most use Youtube, Facebook, Whatsapp, Instagram, and Twitter. Within a day, every Indonesian on average spends 3 hours 20 minutes to access social media. The large number of social media users in Indonesia is certainly the main attraction for the presidential / vice presidential winning team. No wonder every faction has a special team tasked with targeting social media users .[8] According to Newman (1994), the actual "political product" is a form of campaign, which consists of a number of elements, including: (1) an electoral program based on political and economic guidelines from the party it owns or the organization formed for the election period; (2) its position on the most important issues that emerged during the campaign; (3) candidate image; (4) his reference to his political background and the voter groups that support him. [9]. Referring to Cass R Sunstein in his book \#Republic: Divided Democracy in the Age of Social Media (2017), there are at least three advantages of using social media as a media for political campaigns, including the Presidential Election

First, it is easily accessible to prospective voters. A report from We Are Social (2017) shows that out of 132 million social media users in RI, 120 million of them access social media through mobile devices, smartphones, or tablets. Campaigning through social media allows campaign messages to be spread easily and inexpensively.

Second, broad reach. Unlike conventional-traditional campaign media, social media goes beyond geographical boundaries. Furthermore, the reach of the campaign through social media enables targeted political messages to be delivered. Through Facebook Ads, for example, election campaign messages can be adjusted to the demographic conditions of potential voters so that they are more measurable and on target.

Third, involving potential voters. Quoting Mike Eckstein, a social media researcher from Australia, "Social media is much about engagement" (2018). Social Media is a matter of involvement with others. The use of social media in the presidential election campaign allows prospective voters to not just passively accept campaign messages. However, more than that, open space for interaction and discussion: like, make comments, or share campaign messages with other social media users.

\section{Conclusion}

The election of president and vice president becomes part of democracy. In the era of being digitalized, democracy entered a new era of virtual democracy. The use of social media has become a campaign media and interaction between candidates and supporters and / or netizens, Indonesia is entering the era of virtual democracy as a cyber culture. This new culture is still limited to media campaigns and interactions, not yet able to touch the substance of democracy. Extremely weak political education and digital media literacy, virtual democracy, filled with hashtags and political symbol celebrations between competing candidates. In fact, not infrequently a media forming negative opinions, expressions of hatred and hoaks are very sensitive. Virtual democracy requires media literacy in a more responsible and sustainable way

\section{Acknowledgments}

The research was carried out on social media, twitter with virtual ethnography.analysis. 


\section{References}

Actually, I would says thank you very much..

[1] A. Ardipandanto, "KPU DAN KAMPANYE PILPRES 2019 DI MEDIA SOSIAL," Kaji. Singk. TERHADAP ISU Aktual DAN Strateg., vol. x, no. 19, 2018.

[2] S. S. Firmansyah Mas Agus, Siti Karlinah, "KAMPANYE PILPRES 2014 DALAM KONSTRUKSI AKUN TWITTER PENDUKUNG CAPRES," THE MESSENGER, vol. 9, no. 1, pp. 79-90, 2017.

[3] R. S. Nunik Nurhayati, "Democratic Challenges of Indonesia in the Social Media Era DEMOCRATIC," Dipenogoro Law Rev., vol. 2, 2017.

[4] S. Sumartias, "Teori Pemasaran Politik,” Unpad Press, 2018.

[5] suwandi sumartias, "Political Branding Politisi di Indonesia," Unpad Press, 2018.

[6] K. Marijan, "The study of political culture," Masy. Kebud. dan Polit., vol. XII, no. 2, pp. 57-66, 1999.

[7] P. P. Rachmaniar, "Public Relations and Branding," in PUBLIC RELATIONS AND BRANDING, S. D. P. Subekti, S. L. R. Dewi, and F. A. A. Prastowo, Eds. Unpad Press, 2017.

[8] M. A. Hidayat, “Kampanye Pilpres di Era Media Sosial,” Media Indonesia, no. 2018, pp. 2018-2020, 2018.

[9] B. I. . W. C. A. F. Newman, Political Marketing. Routledge 2 Park Square, Milton Park, Abingdon, Oxon OX14 4RN 711 Third Avenue, New York, NY 10017, USA, 2015. 